\title{
Sphingopyxis baekryungensis sp. nov., an orange-pigmented bacterium isolated from sea water of the Yellow Sea in Korea
}

\author{
Jung-Hoon Yoon, ${ }^{1}$ Choong-Hwan Lee, ${ }^{1}$ Soo-Hwan Yeo ${ }^{2}$ \\ and Tae-Kwang $\mathrm{Oh}^{1}$
${ }^{1}$ Laboratory of Microbial Function, Korea Research Institute of Bioscience and Biotechnology (KRIBB), PO Box 115, Yusong, Taejon, Korea \\ ${ }^{2}$ Center for Traditional Microorganism Resources, Keimyung University, Shindang-dong, \\ Dalseo-gu, Daegu, Korea
}

Correspondence

Jung-Hoon Yoon

\begin{abstract}
A Gram-negative, motile, slightly halophilic bacterial strain, $\mathrm{SW}-150^{\top}$, was isolated from sea water of the Yellow Sea, Korea, and was characterized by a polyphasic taxonomic approach. Strain SW $-150^{\top}$ grew optimally at $25-30^{\circ} \mathrm{C}$ and in the presence of $2 \%(\mathrm{w} / \mathrm{v}) \mathrm{NaCl}$. The isolate could be distinguished from other Sphingopyxis species in producing an orange pigment. It contained ubiquinone-10 as the predominant respiratory lipoquinone and $\mathrm{C}_{18: 1} \omega 7 \mathrm{c}$ and $\mathrm{C}_{17: 1} \omega 6 \mathrm{c}$ as the major fatty acids. No 3-hydroxy fatty acids were detected. Major polar lipids were sphingoglycolipid, diphosphatidylglycerol, phosphatidylglycerol and phosphatidylethanolamine. The DNA G $+\mathrm{C}$ content was $63 \mathrm{~mol} \%$. Comparative $16 \mathrm{~S}$ rRNA gene sequence analyses showed that strain $S W-150^{\top}$ was phylogenetically affiliated to the genus Sphingopyxis of the family Sphingomonadaceae. Similarity values between the 16S rRNA gene sequences of strain $\mathrm{SW}-150^{\top}$ and the type strains of Sphingopyxis species ranged from $91 \cdot 6$ to $94 \cdot 2 \%$, making it possible to categorize strain $\mathrm{SW}-150^{\top}$ as a species that is separate from previously described Sphingopyxis species. On the basis of phenotypic properties and phylogenetic distinctiveness, SW-150 $\left(=\right.$ KCTC $12231^{\top}=$ DSM $\left.16222^{\top}\right)$ should be classified as the type strain of a novel Sphingopyxis species, for which the name Sphingopyxis baekryungensis sp. nov. is proposed.
\end{abstract}

Takeuchi et al. (2001) proposed that Sphingomonas species should be assigned to three different genera, Sphingobium, Novosphingobium and Sphingopyxis, in addition to the genus Sphingomonas sensu stricto. Although Yabuuchi et al. (2002) proposed that there is no phenotypic and phylogenetic evidence to divide the genus Sphingomonas into the four genera, the nomenclature of Takeuchi et al. (2001) is in common use (Kämpfer et al., 2002; Busse et al., 2003; Fujii et al., 2003; Godoy et al., 2003; Ushiba et al., 2003; Sohn et al., 2004). At present the genus Sphingopyxis comprises six species: Sphingopyxis macrogoltabida (Takeuchi et al., 1993, 2001), Sphingopyxis terrae (Takeuchi et al., 1993, 2001), Sphingopyxis witflariensis (Kämpfer et al., 2002), Sphingopyxis alaskensis (Vancanneyt et al., 2001; Godoy et al., 2003), Sphingopyxis chilensis (Godoy et al., 2003) and

Published online ahead of print on 21 January 2005 as DOI 10.1099/ ijs.0.63495-0.

The GenBank/EMBL/DDBJ accession number for the 16S rRNA gene sequence of strain $\mathrm{SW}-150^{\top}$ is AY608604.

The tree from which Fig. 1 was taken is available as supplementary material in IJSEM Online.
Sphingopyxis flavimaris (Yoon \& Oh, 2005). Recently, an orange-pigmented Sphingopyxis-like bacterium, SW- $150^{\mathrm{T}}$, was isolated from sea water of the Yellow Sea, Korea. To date, all members allocated to the genus Sphingopyxis are yellow-pigmented (Takeuchi et al., 1993; Kämpfer et al., 2002; Godoy et al., 2003; Yoon \& Oh, 2005). Accordingly, the aim of the present work was to determine the exact taxonomic position of strain $\mathrm{SW}-150^{\mathrm{T}}$ by using a polyphasic taxonomic characterization.

Sea water collected from Baekryung Island in the Yellow Sea in Korea was used as a source for isolation of bacterial strains. Strain $\mathrm{SW}-150^{\mathrm{T}}$ was isolated by the usual dilutionplating technique on marine agar 2216 (MA; Difco) at $30^{\circ} \mathrm{C}$. Cell morphology was examined by light microscopy (E600; Nikon) and transmission electron microscopy (TEM). The presence of flagella was investigated by TEM, using cells from exponentially growing cultures. The Gram-reaction was determined by using the bioMérieux Gram Stain kit, according to the manufacturer's instructions. Growth at various $\mathrm{NaCl}$ concentrations was investigated in marine broth 2216 (MB; Difco) or in trypticase soy broth (Difco). 
Growth in the absence of $\mathrm{NaCl}$ was investigated in trypticase soy broth without $\mathrm{NaCl}$. Growth at various temperatures $\left(4-40^{\circ} \mathrm{C}\right)$ was measured on MA. The $\mathrm{pH}$ range for growth was determined in $\mathrm{MB}$ that was adjusted to various $\mathrm{pH}$ values ( $\mathrm{pH} 4 \cdot 5-9 \cdot 5$ at intervals of $0 \cdot 5 \mathrm{pH}$ units). Growth under anaerobic conditions was determined after incubation in an anaerobic chamber on MA and on MA supplemented with nitrate, both of which had been prepared anaerobically using nitrogen. Catalase and oxidase activities, and hydrolysis of casein, starch and Tweens 20, 40, 60 and 80, were determined as described by Cowan \& Steel (1965). Hydrolysis of hypoxanthine, tyrosine and xanthine was investigated on MA, with the substrate concentrations described by Cowan \& Steel (1965). Hydrolysis of aesculin, gelatin and urea, and nitrate reduction, were studied as described previously (Lanyi, 1987), except that artificial sea water was used for preparation of media. The artificial sea water contained (per litre distilled water): $23.6 \mathrm{~g} \mathrm{NaCl}, 0.64 \mathrm{~g} \mathrm{KCl}, 4.53 \mathrm{~g} \mathrm{MgCl}_{2} .6 \mathrm{H}_{2} \mathrm{O}, 5.94 \mathrm{~g}$ $\mathrm{MgSO}_{4} .7 \mathrm{H}_{2} \mathrm{O}$ and $1.3 \mathrm{~g} \mathrm{CaCl}_{2} \cdot 2 \mathrm{H}_{2} \mathrm{O}$ (Bruns et al., 2001). $\mathrm{H}_{2} \mathrm{~S}$ production was tested as described previously (Bruns et al., 2001). Acid production from carbohydrates was determined as described by Leifson (1963). Utilization of substrates as sole carbon and energy sources was tested according to the method of Baumann \& Baumann (1981), supplemented with $2 \%(\mathrm{v} / \mathrm{v})$ Hutner's mineral base (Cohen-Bazire et al., 1957) and $1 \%(\mathrm{v} / \mathrm{v})$ vitamin solution (Staley, 1968). For in vivo pigment-absorption spectrum

Table 1. Differential phenotypic characteristics of Sphingopyxis species and Sphingomonas taejonensis

Species: 1, Sphingopyxis baekryungensis sp. nov. $(n=1)$; 2, Sphingopyxis macrogoltabida $(n=6)$ (data from Takeuchi et al., 1993, 1995; Kämpfer et al., 1997; Lee et al., 2001); 3, Sphingopyxis terrae ( $n=6)$ (Takeuchi et al., 1993, 1995; Kämpfer et al., 1997; Lee et al., 2001); 4, Sphingopyxis alaskensis $(n=7)$ (Vancanneyt et al., 2001); 5, Sphingopyxis chilensis $(n=1)$ (Godoy et al., 2003); 6, S. witflariensis ( $n=1$ ) (Kämpfer et al., 2002); 7, Sphingopyxis flavimaris $(n=1)$ (Yoon \& Oh, 2005); 8, Sphingomonas taejonensis ( $n=1)$ (Lee et al., 2001). All species are Gram-negative, rod-shaped, non-spore-forming, motile and catalase- and oxidase-positive. All species are negative for utilization of citrate. $n$, Number of strains; +, positive; -, negative; $\mathrm{W}$, weakly positive; ND, not determined; V, variable reaction. Data in parentheses are for the type strain.

\begin{tabular}{|c|c|c|c|c|c|c|c|c|}
\hline Characteristic & 1 & 2 & 3 & 4 & 5 & 6 & 7 & 8 \\
\hline Colony colour & Orange & $\begin{array}{c}\text { Whitish-brown } \\
\text { or yellow }\end{array}$ & $\begin{array}{l}\text { Light- or } \\
\text { deep-yellow }\end{array}$ & $\begin{array}{l}\text { Yellow } \\
\text { to beige }\end{array}$ & Yellow & Yellow & Yellow & Pale-yellow \\
\hline Motility & + & + & $\mathrm{V}(+)$ & + & + & + & + & + \\
\hline Nitrate reduction to nitrite & + & - & - & - & - & - & - & - \\
\hline \multicolumn{9}{|l|}{ Hydrolysis of: } \\
\hline Aesculin & + & $\mathrm{V}(+)$ & $\mathrm{V}(-)$ & + & + & - & - & - \\
\hline Gelatin & - & $\mathrm{V}(-)$ & - & - & - & - & - & - \\
\hline Urea & - & - & - & $\mathrm{v}(+)$ & - & - & - & - \\
\hline \multicolumn{9}{|l|}{ Utilization of: } \\
\hline Acetate & + & $(+)$ & $(-)$ & - & ND & - & - & ND \\
\hline L-Arabinose & + & + & - & - & - & - & - & - \\
\hline Cellobiose & + & + & + & $\mathrm{V}(-)$ & ND & - & + & ND \\
\hline Fructose & - & - & - & - & + & - & - & ND \\
\hline D-Galactose & - & $(-)$ & $(-)$ & $\mathrm{V}(+)$ & ND & - & - & ND \\
\hline D-Glucose & + & $(+)$ & $(-)$ & + & + & + & + & ND \\
\hline Malate & $\mathrm{w}$ & - & + & + & + & - & - & + \\
\hline Maltose & - & + & + & + & + & + & - & - \\
\hline Mannose & + & - & - & - & + & - & - & - \\
\hline Trehalose & - & + & + & + & ND & - & - & ND \\
\hline Xylose & - & - & - & - & $\mathrm{W}$ & - & + & ND \\
\hline \multicolumn{9}{|l|}{$\begin{array}{l}\text { Nucleotide signature of } 16 \mathrm{~S} \\
\text { rRNA gene: }\end{array}$} \\
\hline $134^{\star}$ & G & G & G & G & G & G & A & G \\
\hline $990: 1215^{\star}$ & $\mathrm{U}: \mathrm{A}$ & $\mathrm{U}: \mathrm{G}$ & $\mathrm{U}: \mathrm{G}$ & $\mathrm{U}: \mathrm{G}$ & $\mathrm{U}: \mathrm{G}$ & $\mathrm{U}: \mathrm{A}$ & $\mathrm{U}: \mathrm{A}$ & $\mathrm{U}: \mathrm{G}$ \\
\hline Major fatty acids $\dagger$ & $\begin{array}{l}\mathrm{C}_{18: 1} \omega 7 c \\
\mathrm{C}_{17: 1} \omega 6 c\end{array}$ & $\begin{array}{c}\mathrm{C}_{18: 1} \omega 7 c, \text { iso } \\
\mathrm{C}_{15: 0} 2-\mathrm{OH} / \\
\mathrm{C}_{16: 1} \omega 7 c\end{array}$ & $\begin{array}{l}\mathrm{C}_{17: 1} \omega 6 c \\
\mathrm{C}_{18: 1} \omega 7 c\end{array}$ & $\begin{array}{l}\mathrm{C}_{17: 1} \omega 6 c \\
\mathrm{C}_{18: 1} \omega 7 c\end{array}$ & $\begin{array}{l}\mathrm{C}_{18: 1} \omega 7 c \\
\mathrm{C}_{17: 1} \omega 6 c\end{array}$ & $\begin{array}{c}\mathrm{C}_{17: 1} \omega 6 c, \text { iso } \\
\mathrm{C}_{15: 0} 2-\mathrm{OH} / \\
\mathrm{C}_{16: 1} \omega 7 c\end{array}$ & $\begin{array}{c}\mathrm{C}_{18: 1} \omega 7 c, \text { iso } \\
\mathrm{C}_{15: 0} 2-\mathrm{OH} / \\
\mathrm{C}_{16: 1} \omega 7 c, \mathrm{C}_{17: 1} \omega 6 c\end{array}$ & $\begin{array}{l}\mathrm{C}_{18: 1} \omega 7 c / \mathrm{C}_{18: 1} \omega 9 t / \\
\mathrm{C}_{18: 1} \omega 12 t, \mathrm{C}_{16: 0}\end{array}$ \\
\hline DNA $\mathrm{G}+\mathrm{C}$ content $(\mathrm{mol} \%)$ & 63 & $63-65$ & $63-65$ & 65 & 66 & ND & 58 & 63 \\
\hline
\end{tabular}

${ }^{\star}$ E. coli $16 \mathrm{~S}$ rRNA numbering system was used.

$\dagger$ Data from Lee et al. (2001), Vancanneyt et al. (2001), Godoy et al. (2003), Yoon \& Oh (2005) and this study. 
analysis, the strain was cultivated aerobically in the dark at $30{ }^{\circ} \mathrm{C}$ in $\mathrm{MB}$. The cultures were washed twice by centrifugation using MOPS buffer (MOPS/ $\mathrm{NaOH}, 0.01 \mathrm{M} ; \mathrm{KCl}$, $0 \cdot 1 \mathrm{M} ; \mathrm{MgCl}_{2}, 0 \cdot 001 \mathrm{M} ; \mathrm{pH} 7 \cdot 5$ ), and were disrupted by sonication with a Branson Sonifier 450. After removal of cell debris by centrifugation, the absorption spectrum of the supernatant was examined on a Beckman Coulter DU800 spectrophotometer. Other physiological and biochemical tests were performed with the API 20E system (bioMérieux). The morphological, cultural, physiological and biochemical properties of strain SW- $150^{\mathrm{T}}$ are shown in Table 1, or are given in the species description (see below). The sonicated cell extracts showed absorption maximum at $463-464 \mathrm{~nm}$, and methanol-soluble pigment was characterized by absorption maximum at $462 \mathrm{~nm}$.

The 16S rRNA gene was amplified by PCR using two universal primers, as described previously (Yoon et al., 1998). Sequencing of the amplified 16S rRNA gene and phylogenetic analysis were performed as described by Yoon et al. (2003). The almost complete $16 \mathrm{~S}$ rRNA gene sequence of strain $\mathrm{SW}-150^{\mathrm{T}}$ determined in this study comprised 1446 nucleotides, representing approximately $96 \%$ of the Escherichia coli 16S rRNA gene sequence. Comparative $16 \mathrm{~S}$ rRNA gene sequence analyses showed that strain SW-150 ${ }^{\mathrm{T}}$ is phylogenetically most closely related to Sphingopyxis species of the family Sphingomonadaceae, particularly forming a cluster with $S$. flavimaris with a relatively high bootstrap resampling value of $85 \cdot 8 \%$ (Fig. 1). The sequence contained four of five signature nucleotides defined for the genus Sphingopyxis, as described by Takeuchi et al. (2001) (Table 1). Similarity values between the 16S rRNA gene sequences of strain $\mathrm{SW}-150^{\mathrm{T}}$ and the type strains of Sphingopyxis species ranged from $91 \cdot 6 \%$ (with S. terrae) to $94 \cdot 2 \%$ (with S. macrogoltabida and S. chilensis). Sequence similarities to other members used in the phylogenetic analysis were lower than $93.6 \%$ (Fig. 1).
Cell biomass for respiratory lipoquinone and polar lipid analyses and for DNA extraction was obtained from cultivation in $\mathrm{MB}$ at $30^{\circ} \mathrm{C}$. Respiratory lipoquinones were analysed as described previously (Komagata \& Suzuki, 1987), by using reversed-phase HPLC. Chromosomal DNA was isolated and purified according to the method described by Yoon et al. (1996), with the exception that ribonuclease T1 was applied in combination with ribonuclease A. For fatty acid methyl ester (FAME) analysis, a loop of cell mass was harvested from MA plates after cultivation for 7 days at $30^{\circ} \mathrm{C}$. The FAMEs were extracted and prepared according to the standard protocol of the MIDI/Hewlett Packard Microbial Identification System (Sasser, 1990). Polar lipids were extracted according to the procedures described by Minnikin et al. (1984) and were identified by two-dimensional TLC followed by spraying with appropriate detection reagents (Komagata \& Suzuki, 1987). The DNA G+C content was determined by the method of Tamaoka \& Komagata (1984) with the modification that the DNA was hydrolysed and the resultant nucleotides were analysed by reversed-phase HPLC. Strain $\mathrm{SW}-150^{\mathrm{T}}$ contained ubiquinone-10 $(\mathrm{Q}-10)$ as the predominant respiratory lipoquinone, at a peak area ratio of approximately $91 \%$. The major components $(>1 \%)$ of the fatty acids detected in strain $\mathrm{SW}-150^{\mathrm{T}}$ were unsaturated fatty acids $\mathrm{C}_{18: 1} \omega 7 c(33.8 \%), \mathrm{C}_{17: 1} \omega 6 c(18.8 \%), 10$ methyl- $\mathrm{C}_{18: 1} \omega 7 c(5 \cdot 6 \%)$ and $\mathrm{C}_{17: 1} \omega 8 c(2 \cdot 4 \%)$, straightchain fatty acids $\mathrm{C}_{16: 0}(9 \cdot 7 \%), \mathrm{C}_{17: 0}(3 \cdot 9 \%), \mathrm{C}_{15: 0}(2 \cdot 6 \%)$ and $\mathrm{C}_{14: 0}(1 \cdot 2 \%)$, and hydroxy fatty acids $\mathrm{C}_{14: 0} 2-\mathrm{OH}$ $(8 \cdot 9 \%), \mathrm{C}_{15: 0} 2-\mathrm{OH}(4 \cdot 2 \%)$ and $\mathrm{C}_{16: 0} 2-\mathrm{OH}(1 \cdot 1 \%)$. This cellular fatty acid profile was similar to those of some Sphingopyxis species, particularly S. chilensis, although there are differences in the compositions of some fatty acids, which may be caused by different cultivation conditions (Takeuchi et al., 1993; Vancanneyt et al., 2001; Godoy et al., 2003; Yoon \& Oh, 2005) (Table 1). 3-Hydroxy fatty acids were not detected in strain SW-150 ${ }^{\mathrm{T}}$, which was also found

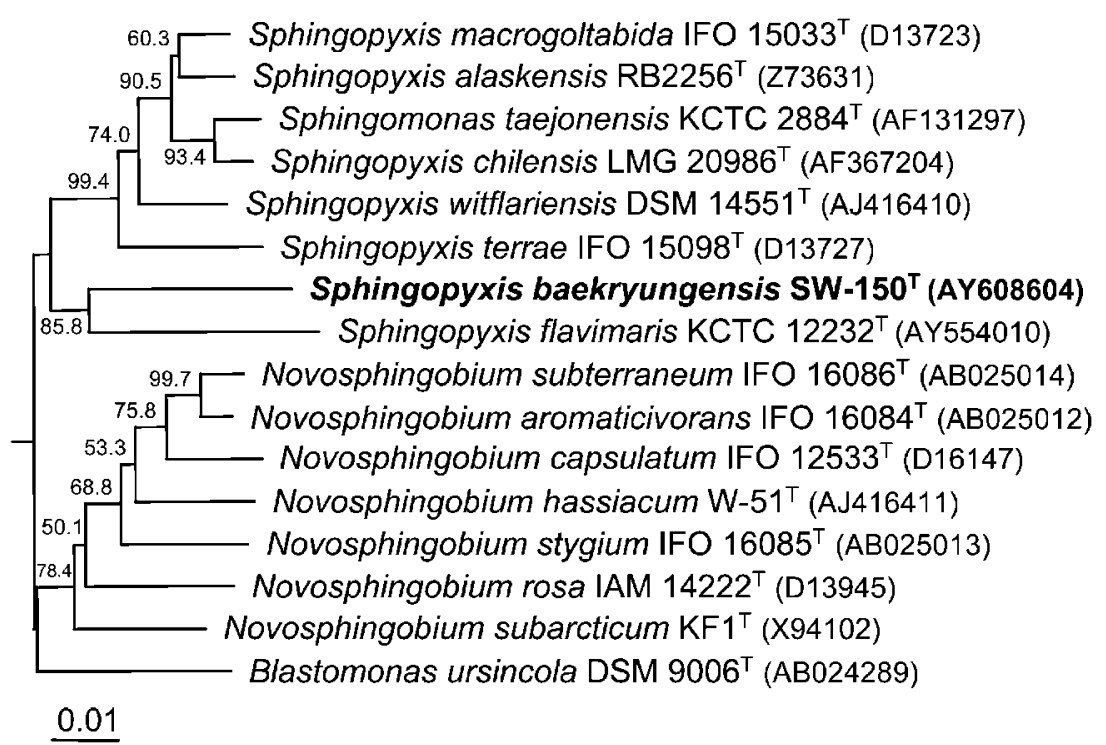

Fig. 1. Neighbour-joining tree based on $16 \mathrm{~S}$ rRNA gene sequence data showing the phylogenetic positions of strain SW-150 and representatives of some related taxa. Bootstrap values (1000 replications) are shown as percentages at each node only if they are $50 \%$ or greater. Bar, 0.01 substitutions per nucleotide position. Rhodospirillum rubrum ATCC $11170^{\top}$ was used as an outgroup. 
for other Sphingopyxis species and all species that were previously assigned to the genus Sphingomonas (Yabuuchi et al., 1990; Takeuchi et al., 1993, 1995; Lee et al., 2001; Vancanneyt et al., 2001; Busse et al., 2003; Godoy et al., 2003). The major polar lipids detected in strain SW- $150^{\mathrm{T}}$ were sphingoglycolipid, diphosphatidylglycerol, phosphatidylglycerol and phosphatidylethanolamine; minor amounts of phosphatidylmonomethylethanolamine, an unidentified glycolipid and unidentified phospholipids were also present. This polar lipid composition is similar to those of four Sphingopyxis species, the data of which have been reported by Kämpfer et al. $(1997,2002)$ and Yoon \& Oh (2005); phosphatidylcholine, which was detected in three Sphingopyxis species with the exception of $S$. flavimaris, was not present (Kämpfer et al., 1997, 2002; Yoon \& Oh, 2005). The DNA G + C content of strain SW $-150^{\mathrm{T}}$ was $63 \mathrm{~mol} \%$. The results obtained from chemotaxonomic analyses, showing the properties that are characteristic of the genus Sphingopyxis, were in agreement with the result of phylogenetic classification based on 16S rRNA gene sequences (Takeuchi et al., 1993; Kämpfer et al., 2002; Vancanneyt et al., 2001; Godoy et al., 2003).

There are not enough phenotypic, particularly chemotaxonomic, properties to distinguish strain $\mathrm{SW}-150^{\mathrm{T}}$ from the genus Sphingopyxis (Takeuchi et al., 1993; Lee et al., 2001; Vancanneyt et al., 2001; Godoy et al., 2003). The orange pigmentation of strain $\mathrm{SW}-150^{\mathrm{T}}$ is not observed in Sphingopyxis species. However, three orange-pigmented species, Sphingomonas aurantiaca, Sphingomonas aerolata and Sphingomonas faeni, were recently assigned to the genus Sphingomonas, which had previously comprised only yellow-pigmented species (Busse et al., 2003). Accordingly, it seems reasonable to assign strain $\mathrm{SW}-150^{\mathrm{T}}$ within the genus Sphingopyxis. The phylogenetic distinctiveness shown in this study is low enough to exclude the possibility of assigning strain $\mathrm{SW}-150^{\mathrm{T}}$ to a Sphingopyxis species with a validly published name, despite the lack of DNA-DNA hybridization experiments between strain $\mathrm{SW}-150^{\mathrm{T}}$ and other Sphingopyxis species (Stackebrandt \& Goebel, 1994). There are differences between strain $\mathrm{SW}-150^{\mathrm{T}}$ and the other six Sphingopyxis species in some phenotypic properties, including pigmentation, nitrate reduction and utilization of some substrates (Table 1). In particular, it is noteworthy that nitrate reduction has not been shown in other recognized Sphingopyxis species (Table 1). Therefore, on the basis of the data presented, strain $\mathrm{SW}-150^{\mathrm{T}}$ should be placed in the genus Sphingopyxis in a novel species, for which the name Sphingopyxis baekryungensis sp. nov. is proposed.

\section{Description of Sphingopyxis baekryungensis sp. nov.}

Sphingopyxis baekryungensis (baek.ryung.en'sis. N.L. fem. adj. baekryungensis of Baekryung Island, an island of the Yellow Sea in Korea where the type strain was isolated).

Cells are ovoid, $0 \cdot 7-0 \cdot 9 \mu \mathrm{m} \times 1 \cdot 5-2 \cdot 5 \mu \mathrm{m}$. Gram-negative.
Non-spore-forming. Motile by means of a single polar flagellum. Colonies are circular, convex, glistening, orange in colour and $0.8-1.0 \mathrm{~mm}$ in diameter after 7 days cultivation at $30{ }^{\circ} \mathrm{C}$ on MA. The sonicated cell extracts show absorption maximum at $463-464 \mathrm{~nm}$. Methanolsoluble pigment shows absorption maximum at $462 \mathrm{~nm}$. Optimal growth temperature is $25-30{ }^{\circ} \mathrm{C}$; growth occurs at $4{ }^{\circ} \mathrm{C}$, but not at $37^{\circ} \mathrm{C}$. Optimal $\mathrm{pH}$ for growth is $7 \cdot 0-8 \cdot 0$; growth occurs at $\mathrm{pH} 4 \cdot 5$, but not at $\mathrm{pH} 4 \cdot 0$. Optimal growth occurs in the presence of $2 \%(\mathrm{w} / \mathrm{v}) \mathrm{NaCl}$; growth occurs in the presence of $10 \%(\mathrm{w} / \mathrm{v}) \mathrm{NaCl}$, but not without $\mathrm{NaCl}$ and in the presence of $>11 \%(w / v) \mathrm{NaCl}$. Growth does not occur under anaerobic conditions on MA and on MA supplemented with nitrate. Tweens 20, 40, 60 and 80 are hydrolysed. Casein, starch, hypoxanthine, tyrosine and xanthine are not hydrolysed. $\mathrm{H}_{2} \mathrm{~S}$ and indole are not produced. Arginine dihydrolase, lysine decarboxylase, ornithine decarboxylase and tryptophan deaminase are absent. Pyruvate is utilized. Lactose, sucrose, succinate, benzoate, formate and L-glutamate are not utilized. Acid is produced from L-arabinose, D-galactose and D-glucose, and weakly produced from D-cellobiose and sucrose. No acid is formed from the following substrates: adonitol, D-fructose, lactose, maltose, D-mannitol, D-mannose, D-melezitose, melibiose, myo-inositol, D-raffinose, L-rhamnose, D-ribose, D-sorbitol, D-trehalose or D-xylose. The predominant respiratory lipoquinone is $\mathrm{Q}-10$. The major fatty acids are $\mathrm{C}_{18: 1} \omega 7 c(33 \cdot 8 \%)$ and $\mathrm{C}_{17: 1} \omega 6 c(18 \cdot 8 \%) ; 2$-hydroxy fatty acids are detected. Major polar lipids are sphingoglycolipid, diphosphatidylglycerol, phosphatidylglycerol and phosphatidylethanolamine. The DNA G+C content is $63 \mathrm{~mol} \%$ (determined by HPLC). Other phenotypic properties are given in Table 1.

The type strain, SW $-150^{\mathrm{T}}\left(=\right.$ KCTC $\left.12231^{\mathrm{T}}=\mathrm{DSM} 16222^{\mathrm{T}}\right)$, was isolated from sea water at Baekryung Island in the Yellow Sea in Korea.

\section{Acknowledgements}

This work was supported by the 21C Frontier program of Microbial Genomics and Applications (grant MG02-0401-001-1-0-0) from the Ministry of Science and Technology (MOST) of the Republic of Korea.

\section{References}

Baumann, P. \& Baumann, L. (1981). The marine Gram-negative eubacteria: genera Photobacterium, Beneckea, Alteromonas, Pseudomonas, and Alcaligenes. In The Prokaryotes, pp. 1302-1331. Edited by M. P. Starr, H. Stolp, H. G. Trüper, A. Balows \& H. G. Schlegel. Berlin: Springer.

Bruns, A., Rohde, M. \& Berthe-Corti, L. (2001). Muricauda ruestringensis gen. nov., sp. nov., a facultatively anaerobic, appendaged bacterium from German North Sea intertidal sediment. Int J Syst Evol Microbiol 51, 1997-2006.

Busse, H.-J., Denner, E. B. M., Buczolits, S., Salkinoja-Salonen, M., Bennasar, A. \& Kämpfer, P. (2003). Sphingomonas aurantiaca sp. nov., Sphingomonas aerolata sp. nov. and Sphingomonas faeni sp. nov., air- and dustborne and Antarctic, orange-pigmented, 
psychrotolerant bacteria, and emended description of the genus Sphingomonas. Int J Syst Evol Microbiol 53, 1253-1260.

Cohen-Bazire, G., Sistrom, W. R. \& Stanier, R. Y. (1957). Kinetic studies of pigment synthesis by nonsulfur purple bacteria. J Cell Comp Physiol 49, 25-68.

Cowan, S. T. \& Steel, K. J. (1965). Manual for the Identification of Medical Bacteria. London: Cambridge University Press.

Fujii, K., Satomi, M., Morita, N., Motomura, T., Tanaka, T. \& Kikuchi, S. (2003). Novosphingobium tardaugens sp. nov., an oestradiol-degrading bacterium isolated from activated sludge of a sewage treatment plant in Tokyo. Int J Syst Evol Microbiol 53, 47-52.

Godoy, F., Vancanneyt, M., Martínez, M., Steinbüchel, A., Swings, J. \& Rehm, B. H. A. (2003). Sphingopyxis chilensis sp. nov., a chlorophenol-degrading bacterium that accumulates polyhydroxyalkanoate, and transfer of Sphingomonas alaskensis to Sphingopyxis alaskensis comb. nov. Int J Syst Evol Microbiol 53, 473-477.

Kämpfer, P., Denner, E. B. M., Meyer, S., Moore, E. R. B. \& Busse, H.-J. (1997). Classification of "Pseudomonas azotocolligans" Anderson 1955, 132, in the genus Sphingomonas as Sphingomonas trueperi sp. nov. Int J Syst Bacteriol 47, 577-583.

Kämpfer, P., Witzenberger, R., Denner, E. B. M., Busse, H.-J. \& Neef, A. (2002). Sphingopyxis witflariensis sp. nov., isolated from activated sludge. Int J Syst Evol Microbiol 52, 2029-2034.

Komagata, K. \& Suzuki, K.-I. (1987). Lipids and cell-wall analysis in bacterial systematics. Methods Microbiol 19, 161-207.

Lanyi, B. (1987). Classical and rapid identification methods for medically important bacteria. Methods Microbiol 19, 1-67.

Lee, J.-S., Shin, Y. K., Yoon, J.-H., Takeuchi, M., Pyun, Y.-R. \& Park, Y.-H. (2001). Sphingomonas aquatilis sp. nov., Sphingomonas koreensis sp. nov. and Sphingomonas taejonensis sp. nov., yellow-pigmented bacteria isolated from natural mineral water. Int J Syst Evol Microbiol 51, 1491-1498.

Leifson, E. (1963). Determination of carbohydrate metabolism of marine bacteria. J Bacteriol 85, 1183-1184.

Minnikin, D. E., O’Donnell, A. G., Goodfellow, M., Alderson, G., Athalye, M., Schaal, A. \& Parlett, J. H. (1984). An integrated procedure for the extraction of bacterial isoprenoid quinones and polar lipids. J Microbiol Methods 2, 233-241.

Sasser, M. (1990). Identification of Bacteria by Gas Chromatography of Cellular Fatty Acids. Newark, DE: MIDI.

Sohn, J. H., Kwon, K. K., Kang, J.-H., Jung, H.-B. \& Kim, S.-J. (2004). Novosphingobium pentaromativorans sp. nov., a high-molecular-mass polycyclic aromatic hydrocarbon-degrading bacterium isolated from estuarine sediment. Int J Syst Evol Microbiol 54, 1483-1487.

Stackebrandt, E. \& Goebel, B. M. (1994). Taxonomic note: a place for DNA-DNA reassociation and 16S rRNA sequence analysis in the present species definition in bacteriology. Int J Syst Bacteriol 44, 846-849.

Staley, J. T. (1968). Prosthecomicrobium and Ancalomicrobium: new prosthecate freshwater bacteria. J Bacteriol 95, 1921-1942.
Takeuchi, M., Kawai, F., Shimada, Y. \& Yokota, A. (1993). Taxonomic study of polyethylene glycol-utilizing bacteria: emended description of the genus Sphingomonas and new descriptions of Sphingomonas macrogoltabidus sp. nov., Sphingomonas sanguis sp. nov. and Sphingomonas terrae sp. nov. Syst Appl Microbiol 16, 227-238.

Takeuchi, M., Sakane, T., Yanagi, M., Yamasato, K., Hamana, K. \& Yokota, A. (1995). Taxonomic study of bacteria isolated from plants: proposal of Sphingomonas rosa sp. nov., Sphingomonas pruni sp. nov., Sphingomonas asaccharolytica sp. nov., and Sphingomonas mali sp. nov. Int J Syst Bacteriol 45, 334-341.

Takeuchi, M., Hamana, K. \& Hiraishi, A. (2001). Proposal of the genus Sphingomonas sensu stricto and three new genera, Sphingobium, Novosphingobium and Sphingopyxis, on the basis of phylogenetic and chemotaxonomic analyses. Int J Syst Evol Microbiol 51, 1405-1417.

Tamaoka, J. \& Komagata, K. (1984). Determination of DNA base composition by reverse-phase high-performance liquid chromatography. FEMS Microbiol Lett 25, 125-128.

Ushiba, Y., Takahara, Y. \& Ohta, H. (2003). Sphingobium amiense sp. nov., a novel nonylphenol-degrading bacterium isolated from a river sediment. Int J Syst Evol Microbiol 53, 2045-2048.

Vancanneyt, M., Schut, F., Snauwaert, C., Goris, J., Swings, J. \& Gottschal, J. C. (2001). Sphingomonas alaskensis sp. nov., a dominant bacterium from a marine oligotrophic environment. Int J Syst Evol Microbiol 51, 73-79.

Yabuuchi, E., Yano, I., Oyaizu, H., Hashimoto, Y., Ezaki, T. \& Yamamoto, H. (1990). Proposals of Sphingomonas paucimobilis gen. nov. and comb. nov., Sphingomonas parapaucimobilis sp. nov., Sphingomonas yanoikuyae sp. nov., Sphingomonas adhaesiva sp. nov., Sphingomonas capsulate comb. nov., and two genospecies of the genus Sphingomonas. Microbiol Immunol 34, 99-119.

Yabuuchi, E., Kosako, Y., Fujiwara, N., Naka, T., Matsunaga, I., Ogura, H. \& Kobayashi, K. (2002). Emendation of the genus Sphingomonas Yabuuchi et al. 1990 and junior objective synonymy of the species of three genera, Sphingobium, Novosphingobium and Sphingopyxis, in conjunction with Blastomonas ursincola. Int J Syst Evol Microbiol 52, 1485-1496.

Yoon, J.-H. \& Oh, T.-K. (2005). Sphingopyxis flavimaris sp. nov., isolated from sea water of the Yellow Sea in Korea. Int J Syst Evol Microbiol 55, 369-373.

Yoon, J.-H., Kim, H., Kim, S.-B., Kim, H.-J., Kim, W. Y., Lee, S. T., Goodfellow, M. \& Park, Y.-H. (1996). Identification of Saccharomonospora strains by the use of genomic DNA fragments and rRNA gene probes. Int J Syst Bacteriol 46, 502-505.

Yoon, J.-H., Lee, S. T. \& Park, Y.-H. (1998). Inter- and intraspecific phylogenetic analysis of the genus Nocardioides and related taxa based on 16S rDNA sequences. Int J Syst Bacteriol 48, 187-194.

Yoon, J.-H., Kim, H., Kim, I.-G., Kang, K. H. \& Park, Y.-H. (2003). Erythrobacter flavus sp. nov., a slight halophile from the East Sea in Korea. Int J Syst Evol Microbiol 53, 1169-1174. 